\title{
Examining the Impact of Training and Nativeness on Teacher's self-efficacy in teaching English
}

\author{
Lina Lafta Jassim \\ College of Art, University of ThiQar \\ Lfnar83@gmail.com
}

\begin{abstract}
The purpose of this study was to examine the impact of training and 'nativeness' on teacher's self-efficacy in teaching English as a second language. A questionnaire was used and administered to 281 foreign teachers in Nasseria, Iraq. The teacher's sense of efficacy scale (TSES) was employed to measure a teacher's selfefficacy. Using MANOVA, we tested the impact of teachers' training and 'nativeness' on a teacher's selfefficacy. The analysis showed that trained teachers have higher self-efficacy than untrained teachers and further that professional development enhances self-efficacy. The study established that being a native speaker does not necessarily influence a teacher's self-efficacy and goes to support the hypothesis that target language proficiency should not be associated with being a language teacher. Ultimately, policymakers and educational administrators should concentrate on the professional development of language teachers and disband the native/non-native dichotomy.
\end{abstract}

Keywords: Teachers; Self-efficacy; Teaching English; Teacher Training; Nativeness

\subsection{Introduction}

Over the years, Iraq has attracted an increasing number of people from various professions and talents as a result of its growing economic potential. This situation is true, especially for professional teachers and other people (non-professional teachers) who have an interest in teaching English. English is the most popular international language in Iraq and is considered as the first global language (Gil, 2011). As a result, knowledge, and understanding of the English language present an added advantage to many Arabic in light of the new 'one belt and one road' policy which is one of many policies which seeks to extend Iraq's global relationship with the rest of the world (Aoyama, 2016).

Linking Iraq to the rest of the world will require the use of the English language as a medium of communication since the Arabic language does not enjoy huge currency in the rest of the world. Accordingly, the English Language has been made a compulsory subject of study in the Arabic educational curriculum beginning from primary through to the tertiary level of education (Braine, 2012). According to Zheng and Zhang (2014), in 2013 alone, there were about 300 million Arabic learning English in Iraq, with only about 100,000 foreign English teachers. Similarly, there was a $298 \%$ growth in the English education market in Iraq between 2016 and 2017 alone, from $¥ 123.6$ billion to $¥ 489.7$ billion (Farrell, 2018). Following a report by Beijing News, several studies reported that most foreign teachers working at English training institutions in Iraq did not possess the required qualifications (Zheng \& Zhang, 2014). This was perhaps aimed at painting a gloomy picture in respect of the limited employment avenues for native Arabic. Generally, however, there is an imbalance between the demand for and the supply of qualified professional English teachers. Hence, schools are compelled to fill this gap with unqualified persons (mostly non-professionals). For this reason, tourists, international students, and foreign professional teachers in Iraq have taken advantage of the situation and are engaged in teaching English at various levels. Similar to the case of Iran (Eslami \& Fatahi,

2008), Iraq uses two main channels of recruitment for English-as-a-foreign-language (EFL): These are statesponsored programs in TEFL, and free training for Bachelor's or Master's holders of English language and translation or English literature and others with relevant command of the English language. In such situations, a person's belief in his/her abilities and capabilities plays a significant role in determining the output of these teachers. Self-efficacy plays a vital part in the teaching and learning process because of its dual role in either helping or hindering the learner's progress (Bandura, 2010). On the part of the teacher, intrinsic confidence determines his/her performance to a considerable extent and influences his/her retention on the job. 
On arriving in a new environment such as Iraq, even professional teachers who do not have a grasp of the teaching philosophy of the country are faced with many challenges in the teaching of English as a second language (TEFL). According to Hu (2002) the typical approach to TEFL in Iraq, as part of its culture of learning, has been a combination of the audiolingual and grammar-translation methods, which is mainly characterized by cross-linguistic comparisons and a detailed study of grammar through the memorization of vocabulary and sentence structure with an emphasis on oral and written language and a penchant for literary works. There is a direct contrast with communicative language teaching (CLT), mostly used in English language teaching and learning. In this teaching method, meaning is primary, and teaching should be focused on communicative functions, rather than only linguistic knowledge, and the capacity to use structural patterns (Brown, 2001). The introduction of the communicative CLT approach is considered an alien methodology that is at variance with the traditional teaching method condensed into the 'four R's and four M's' (p. 100). The four R's are reception, repetition, reproduction, and review. The four M's represent memorization, meticulosity, mastery, and mental activeness. In the opinion of $\mathrm{Hu}$ (ibid), the significant factors that pose a potential conflict in the application of CLT in the Arabic culture of learning are the embodiment of different and opposing philosophies in teaching and learning. For this reason, foreign teachers' self-efficacy will be necessary for teaching and learning.

There is an emerging argument that target language proficiency should not be associated with nativeness; rather, adequate preparedness through training should be one of the main criteria for assessing the credentials of both native and nonnative teachers (Braine, 2010; Medgyes, 2011). Choi and Lee (2016) suggest further that professional training and target language proficiency are vital requirements for second language teachers and form the sources of teacher's self-confidence. They note that the preferred teacher is one who has both traits, whereas teachers who have insufficient levels of both are least preferred. Notable studies exist in language teacher's proficiency/nativeness (Choi and Lee, 2016; Eslami and Fatahi, 2008), teachers' development (Chiang, 2008) and self-efficacy (Mojavezi and Tamiz, 2012).

While researchers such as Cheung (2008) have carried out similar studies like the present one in the Arabic context, to the best of our knowledge, none of them combines all the variables used in this study. Also, considering that an estimated 80\% of language teachers are non-native speakers of English (Braine, 2018), we follow Choi and Lee's (2016) conclusion, and test whether being trained and/or being a native teacher influences self-efficacy in specific areas of teaching such as classroom management, instructional strategies and student engagement (which form the three dimensions of the teacher sense of efficacy scale (TSES)). The study, therefore, presents a two-fold dimension to understanding the effects of English language teachers' self-efficacy as far as Iraq is concerned. Using multivariate analysis of variance (MANOVA), the paper assesses these relationships to establish whether teachers' training and/or nativeness result in higher selfefficacy and better performance.

\subsection{Theoretical background}

\subsubsection{Teachers' self-efficacy}

Self-efficacy, as defined by Bandura (Bandura, 2010: 1), is defined as people's beliefs about their capabilities to produce designated levels of performance that exercise influence over events that affect their lives. To Maddux (2002) self-efficacy is what a person believes he/she can do with his/her abilities and skills under certain conditions. Teacher self-efficacy may be explained as teachers' personal beliefs in their ability to carry out activities through adequate planning, and organizing, to attain set educational goals (Skaalvik and Skaalvik, 2010). It is also about how teachers utilize their competence and professional discipline to influence students' behavior, knowledge and values (Tschannen-Moran and Hoy, 2001). It depicts what teachers can do in a particular situation, not what they have accomplished or why it was accomplished in the past (Hoy, 2004). The self-efficacy of teachers involves the choice of activities, effort, and persistence. People with minimal self-efficacy are unlikely to engage in challenging tasks, whereas individuals with a high sense of self-efficacy are more persistent and enduring even when they face difficulties.

'Teachers' self-efficacy' was developed out of the work of the Research and Development (RAND) corporation with a focus on the degree to which teachers believed in whether their ability to take charge of reinforcement was within their remit or in that of the environment (Rotter, 1966). Student motivation and performance were presumed to be significant reinforcers for teaching behaviors. The expectation, in the view of the RAND researchers, is that high levels of teachers' self-efficacy could strongly influence students' motivation and achievement. A second view of the theory emerged as a result of the research of Bandura 
(1977). In his view, teachers' self-efficacy is a cognitive process in which individuals build self-beliefs about their ability to accomplish a task within acceptable limits. This sense of self-believe controls the amount of energy expended as well as the endurance and persistence required to face and overcome challenges. These two views of the theory form the underpinnings of teachers' self-efficacy but undoubtedly create gaps related to the clarity of the theory. Some of these issues border on whether teachers' self-efficacy is a one size fits all or whether it is specific to certain conditions and whether the theory needs refinement to capture other vital areas of assessment (Jassim,2018). Teachers' self-efficacy is also related to classroom organization, levels of persistence on a task, instructional strategies, questioning techniques, innovation, degree of risktaking, management of students' on-task time, and teacher feedback to students (Gibson \& Dembo, 1984). The TSES concentrates on classroom management, student engagement activities, and instructional strategies as the three cardinal areas of teacher's self-efficacy.

Hoy and Weinstein (2015) describe classroom management as an overarching term comprising the creation of a productive, orderly learning environment to influence students' behavioral changes and guide them to accomplish their objectives. Recent studies and theoretical developments describe classroom management along two continuums: structure versus chaos, and autonomy support versus control (Jang et al., 2010). Furthermore, many novice teachers believe that managing their classroom is a prerequisite to teaching content (Cochran-Smith and Villegas, 2016); nonetheless, studies have demonstrated that novice teachers have weaker classroom climates than experienced teachers. Gibson and Dembo (1984) suggest that teachers' perceptions of their competence influence their choice of classroom management strategies. Teachers with higher perceptions of self-efficacy are highly effective in using classroom management skills (Goddard, Hoy, \& Hoy, 2004). Such teachers tend to have classrooms that are better planned, more organized, studentcentered, accommodating, and amenable to new ideas (Anthony and Kritsonis, 2007), while teachers with less classroom management skills tend to have classrooms characterized by aggression (Shernoff and Kratochwill, 2007). Henson (2001) finds that teachers who are more practical use enhanced classroom management approaches while Tschannen-Moran et al. (1998) report that a teacher's self-efficacy determines his/her inclination to work with students with difficulties instead of referring them to special education programs. Similarly, Landrum and Kauffman (2015) and Landau (2009) consider the use of rewards and punishment in managing classrooms. They intimate that teachers' main reason for adopting such an approach is to ensure their efficiency since it is an easy way of managing a student's misbehavior, giving teachers a feeling of control.

Four sources of self-efficacy are proposed by Bandura (2010). These are mastery, vicarious experiences, physiological disposition, and social persuasion. Among these sources, mastery is identified as the most common and direct source of self-efficacy according to Goddard et al. (2004). Behavior, personal and environmental factors influence self-efficacy (Bandura, 2010). Mastery experience continuously dominates as a strong force in nurturing teachers' self-efficacy (Bandura, 1997). Engaging students in classroom lessons is a measure of mastery experience. Therefore, there is a marked reinforcement of teachers' self-efficacy when they observe that students are involved in in-class activities. When students have low interest or are not engaged, teachers' responsibilities increase (Ross, Cousins, \& Gadalla, 1996), which goes to undermine their sense of efficacy.

Self-efficacy is specific to each situation and is applied differently among individuals. Teachers' self-efficacy in a classroom may vary according to the subject taught and the grade of the students. Individuals differ in how they nurture their self-efficacy and in the intensity to which they develop it within their area of specialty (Bandura, 2010). For example, a teacher could have high self-efficacy in classroom management but low self-efficacy in student engagement activities. Therefore, the existence of a multi-purpose measure of perceived self-efficacy is a mirage. According to Bandura (1977), the 'one-size-fits-all' method usually has incomplete predictive and explanatory values because the items in an all-purpose test may have little or no bearing on the task. Moreover, to serve all needs, generalized scales ordinarily neglect an individual's specific demands and situations, leading to ambiguity in measurement.

The predisposition of teachers, influenced by, for example, their prior preparation, physical and emotional condition, and external factors such as the setting and demeanor of colleagues, contribute to the level of self-efficacy (Schnuck et al., 2014). Teachers' traits such as gender, grade, level taught, and experience also play a significant role in determining their self-efficacy (Berger et al., 2018). Generally, the ability to succeed raises teachers' self-efficacy, while failure decreases it.

Two major scopes of teachers' perceived efficacy (TES) are discussed in the literature: General Teaching Efficacy (GTE) and Personal Teaching Efficacy (PTE) (Tschannen-Moran and Hoy, 2001). PTE 
signifies a teacher's belief about his/her ability to make a change in a students' performance, while GTE encompasses the teachers' beliefs about the influence of external factors and the teacher's ability to affect the performance of students. Conceptual questions have been raised especially about the GTE, which focuses more on teachers' ability to affect outcomes and noted as a measure of locus of control (Rotter, 1966), a justification for its inaccurate measurement of self-efficacy (Faez and Karas, 2017). The development of what is currently known as the teacher's sense of efficacy scale (TSES) has improved the methodological concerns in the TES (Wyatt, 2014).

According to Wheatley (2002), doubt and uncertainty are sometimes beneficial to a person's selfefficacy. The foundation of Wheatley's challenge to Bandura's (1997) idea is that self-efficacy doubts are a necessary part of teachers' learning and improvement processes. This uncertainty could emanate from a test on teachers' beliefs about their current tasks. To mitigate the impact of teacher's self-efficacy doubts, Wheatley (2002) proposes follow-up coaching.

\subsubsection{Teacher training}

Trained teachers are thought to possess technical competence and to conform to requirements of external authority, which specialist expertise is acquired through lengthy education and training. Under sophisticated professional education, teachers are well qualified to exercise a higher understanding of the nature of learning and pedagogy in meeting the particular and local needs of individual children in particular educational circumstances $(\mathrm{ibid})$. Those in the profession are guided by ethics and teaching standards, which are selfmonitoring mechanisms (Darling-Hammond and Sykes, 1999).

Training is considered a critical criterion in selecting candidates for jobs because of the perception that their expert training is sufficient to enhance their job performance. Tschannen-Moran, Parish, and DiPaola (2006) establish that a teacher's professionalism correlated positively with students' achievement. Among experienced teachers, there is a constancy of self-efficacy beliefs, even with the introduction of new teaching methods (Ross, 1994). Teachers who implement new methods after training experience an increase in their general teaching efficacy and a feeling of greater responsibility both for positive and negative student learning habits, as well as experiencing more positive feelings towards teaching (Guskey, 1984). A study by (Posnanski, 2002) finds that teachers trained in new methods of teaching science made significant gains in personal teaching self-efficacy similar to other experiments where the acquisition of professional knowledge, training, and coaching in teaching, gave teachers an added advantage(Ross and Bruce, 2007; TschannenMoran and McMaster, 2009).

The definition of teacher training in this study is the formal education and technical training received by an individual to teach based on a well-defined curriculum for a lengthy period and has acquired a recognized certificate to teach a specific subject and level. For this reason, we do not consider only TESOL/TEFL/TESL certificates as teaching certificates because of the option of online methods that are not accompanied by supervised practical training.

\subsubsection{Native and non-native language speakers}

The main criterion for describing a person as a native speaker takes into cognizance the circumstances of acquisition; thus, a native speaker is perceived as someone who acquires a language at childhood (Davies, 2003). Native language represents the language a person acquires in early childhood because it is spoken in the family and/or it is the language of the country where he or she is living (Richard, 1985: 241). This means that it is possible to be a native speaker of two or more languages if they were acquired early in childhood.

Brutt-Griffler and Samimy (2001) think that 'nativeness' is a social construct rather than a linguistic category. The description of English speakers as 'native' or 'non-native' speakers hinges upon several social considerations, such as the notions of what and how a native speaker should look or sound like (ibid). To Mesthrie and Bhatt (2008: 36), the distinction between a native and non-native speaker of English -- long taken for granted in linguistics -- is being increasingly called into question in World English research.

Parental guidance affects language development for native speakers, as language learning begins through engagement with caregivers and parents (National Research Council, 1998). According to Gass and Selinker (2010), being exposed to a language through language input and instruction and socialization with, for instance, English-speaking peers helps in the development of the language (Jia and Aaronson, 2003). This 
category of speakers, according to Kachru (1997), comprises speakers who usually set the standards for English-language proficiency, particularly those from countries where English is the native language for the majority of the people, such as the US and the UK. Following from this, Kachru proposes three descriptions of English speakers around the world. The countries which recognize English as a native language are referred to as the Inner Circle (e.g., Canada, Britain, Australia, Ireland, North America), the Outer Circle treat English as a second language or an official language (e.g., India, Malaysia, Ghana, South Africa, Philippines) and the Expanding Circle are the countries which accept English as a foreign language (e.g., Iraq, Japan, Republic of Korea, Russia). Based on this classification, citizens of countries belonging to the outer and expanding circles are non-native speakers.

Non-native speakers either speak or learn English as a second language (e.g., The Netherlands) or as a foreign language (e.g., Iraq) (Kachru, 1997). A non-native speaker does not have the opportunity to develop through the initial processes of native speakers. It has been claimed that non-native English speaking teachers (NNESTs) face problems in terms of a lack of confidence and the biased attitude of students (Reis and Johnson, 2010) even though they are the majority of the English language teachers. The American Council on the Teaching of Foreign Languages (ACTFL) insist that foreign language teachers should be able to hear, understand, speak, read, and write in the target language with a minimum level of proficiency, either advanced or higher (Omaggio \& Higgs, 1984). The command of a language is a mark of a good teacher. Teaching qualifications, exposure to native speakers, and having lived in an English-speaking country all affect teachers' knowledge of, and self-image regarding the language; the higher the NNEST's proficiency in English, the more confident they become (Reves and Medgyes, 1994).

The goal of learning English varies in every country. In Venezuela, it is used primarily for communicative purposes, whereas in Iraq, it is for business communication in particular. In Venezuela, upon graduation, EFL teachers are hired to teach in high schools without having to pass an exam that shows their English competency; administrators do not require teachers to obtain additional certification to teach English (Chacón, 2005). Venezuela, for example, places a heavy emphasis on descriptive linguistics. Thus, the study of the language at the sentence level (Brutt-Griffler and Samimy, 1999) overlooks the social nature of language as a means of communication and interaction. Generally, teachers in Venezuela may not acquire the communicative competence to perform in the four primary language skills, namely writing, reading, listening and speaking. Without this competency, teachers find themselves unable to use communicative language teaching (CLT) in their English classes (Li, 1998) as they do not consider themselves competent in English, and tend to have a low sense of self-efficacy. In Hong Kong, it was realized that NNESTs were influential in pedagogy, but were found to be weak linguistically. NESTs, on the other hand, had a perceived strength in linguistics but had pedagogical weaknesses (Ma, 2012).

Inadequate knowledge of the language can influence the self-esteem and professional status of the teacher and interfere with simple teaching procedures. Perceived language proficiency is of concern to NNESTs and has an impact on their professional self-esteem and confidence (Brutt-Griffler and Samimy, 1999). In Iran, the implementation of CLT requires EFL teachers to be competent in the English language to teach it. It is expected that EFL teachers use English with functional ability in communicating across language skills (Eslami and Fatahi, 2008). Research points to perceived language proficiency as an essential factor for NNEST since it impacts their professional confidence and self-esteem (Brutt-Griffler and Samimy, 1999).

In concluding this section, we take the definition of the words 'native' and 'non-native,' mostly from Kachru (1997). Native English speakers are considered mainly as those who have English as their first and mother tongue and are recognized as such. Non-native speakers are those who have another language as their mother tongue or L1 and have studied English as a second or foreign language and sometimes adopt it as an official language. Based on the foregoing, we hypothesize that:

H1: Professional teachers have higher self-efficacy than non-professional teachers.

H2: Native English-speaking teachers have higher self-efficacy than non-native English teachers.

\subsection{Method}

\subsubsection{Participants}


The population for the study is foreigners in Iraq, with the sample being foreign English language teachers in kindergartens and training schools living in Nasseria. The participants are people who have taught or teach English in public and private kindergartens and English language training schools. The recruitment of the study group was first through contacts with training schools and convenience sampling. An online questionnaire was distributed to principals of training schools contacted as well as general and known teachers' social media platforms, with specific guidelines on the target groups. In all, two hundred and eightyone (281) responses were obtained out of an expected number of 400, representing a response rate of $61.8 \%$. The variables were measured using self-reported assessments.

The study adopted and modified the 12 item Teacher Sense of Efficacy Scale (TSES) proposed by Tschannen-Moran et al. (1998) which is used not only for general teachers but also for language teachers (Chacón, 2005; Eslami \& Fatahi, 2008; Swanson, 2012). Although other self-efficacy scales exist specifically for language teachers such as the Second/Foreign Language Teacher Efficacy Scale (S/FLTES) developed and used by Swanson (2012; 2010), the S/FLTES is still new and needs further development and testing on a more extensive and diverse S/FL teaching population. The TSES was considered appropriate because of the aspects of teaching that it measures as well as its extensive use and validity. Bandura (2006) makes the point that self-efficacy scales should measure what they purport to measure and should also have both discriminative and predictive validity. Hence the reason for the modification. Statement such as 'I am able to calm down a student who is noisy and disruptive in my English class' (classroom management), 'I can motivate students who show low interest in learning English'(student engagement) and 'I can use a variety of assessment strategies in my English class' (instructional strategies). Respondents were required to indicate their level of agreement to each statement from strongly disagree (1) to strongly agree (5).

The measurement of teacher training was through answers to a self reported assessment such as 'Have you gone through formal teacher training?' which required a simple 'yes' or 'no' answer. Formal teacher training means being trained for not less than one year in instructional and methodological approaches to teaching based on an accepted training curriculum of a specific country. This does not necessarily mean being trained only to teach a language but could include other subjects while excluding online TESOL/TEFL training.

Similarly, 'nativeness' is measured by answering 'yes' or ' $n o$ ' to the question, 'Is English the first language or mother tongue (L1) of your country?'. In response to this question, respondents were expected to indicate whether they were born and bred in a native English-speaking country and/or have English as a first language (L1). This shows whether English is their native language or not based on the operational definition.

\subsubsection{Reliability and internal consistency}

Following Jassim \& Dzakiria (2019). to test the reliability of the TSES, Cronbach's alpha ( $\alpha$ ) values were used. Table 1 provides an overview of the reliability level emerging from Cronbach's alpha statistics. Each of the TSES dimensions (instructional strategies, classroom management, and student engagement activities) showed a high level of reliability and internal consistency based on an acceptable standard of $\alpha<0.70$. An examination for the item-total statistics table indicates that none of the variables examined obtained values $<$ 0.30 .

Table 1 Reliability statistics

\begin{tabular}{lll}
\hline TSES & No. of items & Alpha $(\alpha)$ \\
\hline Instructional strategies & 4 & 0.84 \\
Classroom management & 4 & 0.92 \\
Student engagement activities & 4 & 0.91 \\
\hline
\end{tabular}




\subsection{Analysis}

We used MANOVA in determining whether individuals who are native English speakers have higher levels of self-efficacy in teaching English, as well as whether individuals trained as teachers also have high levels of self-efficacy. MANOVA measures several dependent variables (DVs) in a single experiment, with a better chance of discovering which factor is significant. It also protects against Type I errors that can occur in the conduct of independent multiple ANOVAs and reveals differences that ANOVA tests are unable to discover.

The descriptive statistic in Table 2 shows that a higher number of male respondents $(62.6 \%)$ than females were engaged in teaching jobs in Nasseria Iraq. Among this group of respondents, most $(63.4 \%)$ were 25-34 years old, while people aged 55 years or more represented only $2 \%$. There was a significance in the difference between people who were trained teachers and those who were untrained $(57.6 \%$ and $42.4 \%$, respectively). Individuals with teaching experience ranged from less than five years $(50.5 \%)$ to more than 20 years $(3.6 \%)$. Individuals with training in TEFL represented $76.9 \%$, most of whom were native English speakers $(59.1 \%)$. Foreign teachers had been engaged from less than six months to over five years, with the majority having worked for between one and five years $(40.9 \%)$.

Table 2. Background information of respondents

\begin{tabular}{|c|c|c|c|}
\hline $\mathrm{S} / \mathrm{N}$ & Variable & Frequency & Percent \\
\hline \multirow[t]{3}{*}{1} & Gender & & \\
\hline & Male & 176 & 62.6 \\
\hline & Female & 105 & 37.4 \\
\hline \multirow[t]{6}{*}{2} & Age (years) & & \\
\hline & Below 25 & 34 & 12.1 \\
\hline & $25-34$ & 178 & 63.4 \\
\hline & $35-44$ & 52 & 18.5 \\
\hline & $45-54$ & 13 & 4.6 \\
\hline & 55 and above & 4 & 1.4 \\
\hline \multirow[t]{6}{*}{3} & Education & & \\
\hline & High school & 6 & 2.1 \\
\hline & Diploma & 13 & 4.6 \\
\hline & Bachelor & 145 & 51.6 \\
\hline & Masters & 114 & 40.6 \\
\hline & $\mathrm{PhD}$ & 3 & 1.1 \\
\hline \multirow[t]{3}{*}{4} & Have you gone through formal teacher training? & & \\
\hline & No & 119 & 42.4 \\
\hline & Yes & 162 & 57.6 \\
\hline \multirow[t]{5}{*}{5} & $\begin{array}{l}\text { Is English the first language or mother } \\
\text { tongue (L1) of your country? }\end{array}$ & & \\
\hline & No & & \\
\hline & & 115 & 40.9 \\
\hline & Yes & & \\
\hline & & 166 & 59.1 \\
\hline
\end{tabular}


In Table 3, we show the correlation between the variables of interest. Except for nativeness and student engagement activities that did not show any significance, all other variables were significant. The level of correlation does not pose any collinearity problem.

Table 3 Correlation between variables

\begin{tabular}{|c|c|c|c|c|c|c|}
\hline & & 1 & 2 & 3 & 4 & 5 \\
\hline 1 & Trained & 1 & & & & \\
\hline 2 & Native & $0.134 * *$ & 1 & & & \\
\hline 3 & $\begin{array}{l}\text { Instructional Strategies } \\
\text { (IS) }\end{array}$ & $0.199 * * *$ & $0.103 *$ & 1 & & \\
\hline 4 & $\begin{array}{c}\text { Classroom Management } \\
\qquad(\mathrm{CM})\end{array}$ & $0.188 * * *$ & $0.096^{*}$ & $0.576^{* * *}$ & 1 & \\
\hline 5 & $\begin{array}{l}\text { Student Engagement } \\
(\mathrm{SE})\end{array}$ & $0.220 * * *$ & 0.033 & $0.648 * * *$ & $0.463 * * *$ & 1 \\
\hline
\end{tabular}

Note: indicates significance at $* * * \mathrm{p}<0.01 ; * * \mathrm{p}<0.05 ; * \mathrm{p}<0.1$.

The descriptive statistics presented in Table 4 contain the overall and group means, standard deviations, and the results for each independent variable (IV) and dependent variable (DV). The Table shows a higher mean score for trained teachers who are native speakers in classroom management (29.11) and a mean score of 29.46 in instructional strategies for teachers who are neither untrained nor native speakers.

Table 4 Descriptive statistics

\begin{tabular}{|c|c|c|c|c|c|}
\hline & Trained & Native & Mean & Std. Deviation & $N$ \\
\hline \multirow{4}{*}{$\begin{array}{c}\text { Instructional } \\
\text { Strategies }\end{array}$} & No & Yes & 28.27 & 3.602 & 85 \\
\hline & & No & 29.46 & 3.659 & 45 \\
\hline & Yes & Yes & 29.97 & 3.808 & 75 \\
\hline & & No & 30.45 & 3.468 & 71 \\
\hline \multirow{4}{*}{$\begin{array}{c}\text { Classroom } \\
\text { Management }\end{array}$} & No & Yes & 26.41 & 5.290 & 85 \\
\hline & & No & 28.43 & 5.739 & 45 \\
\hline & Yes & Yes & 29.11 & 4.822 & 75 \\
\hline & & No & 28.96 & 4.269 & 71 \\
\hline \multirow{4}{*}{$\begin{array}{c}\text { Student } \\
\text { Engagement }\end{array}$} & No & Yes & 26.95 & 4.488 & 85 \\
\hline & & No & 26.93 & 5.908 & 45 \\
\hline & Yes & Yes & 28.60 & 4.132 & 75 \\
\hline & & No & 29.55 & 4.249 & 71 \\
\hline
\end{tabular}

Note: $N=276$. 
A homogeneity test using Box's M-test of equality of covariance matrices showed a $p$-value of 0.03 , which means significant differences exist among the independent variables (IV) in the covariance matrices. This is against the assumption of MANOVA, but the sample size and the equal values of each observation could explain the discrepancy. Since there is a violation of this assumption, we used Pillai's Trace for the multivariate test (Olson, 1976). We, therefore, controlled for age, gender, and education to test the effect of the IVs on the DVs. Table 5 shows the multivariate test results, indicating significant relations between the trained teachers and the IV $(F=5.17 * * *$, observed power $=95.9 \%)$ as well as the DV and the IV $(F=1.45$, observed power $=51.2 \%$ ). This shows that nativeness did not influence self-efficacy.

Table 5 Multivariate tests results

\begin{tabular}{llllll}
\hline Effect & Value & F & Sig. & partial $\eta 2$ & Observed power \\
\hline Trained & 0.055 & 5.17 & 0.002 & 0.05 & 0.959 \\
Native & 0.016 & 1.45 & 0.227 & 0.01 & 0.512
\end{tabular}

Note: $* * *$ indicates significance at $\mathrm{p}<0.01 ; * *$ indicates significance at $\mathrm{p}<0.05$

Using the tests of between-subject effects (Table 6) to confirm the hypotheses by checking the individual effect of the IV on the DV, we noted that there was a positive relationship between trained teachers and instructional strategies $(F=8.92, p<0.01$, partial $\eta 2=0.032$, power to detect the effect $=$ $90.9 \%)$. Classroom management was also positively influenced by training $\left(F=6.79, p<0.05\right.$, partial $\eta^{2}$ $=0.025$, power to detect the effect $=83 \%$.). There was a statistical significance in the relationship between trained teachers and student engagement activities $(F=14.52, p<0.01$, partial $\eta 2=0.051$, power to detect the effect $=98.4 \%$ ). Based on these findings, the combined effect as shown in table 5 supports H1.

The second IV (nativeness) did not produce any statistical significance in its relationship with the three dimensions of self-efficacy. For this reason, we conclude that $\mathbf{H 2}$ is not supported.

Table 6: Tests of between-subjects' effects

\begin{tabular}{|c|c|c|c|c|c|c|c|c|c|}
\hline Source & $\begin{array}{l}\text { Dependent } \\
\text { variable }\end{array}$ & $\begin{array}{l}\text { Type } \\
\text { sum } \\
\text { squares } \\
\end{array}$ & $\begin{array}{l}\text { III } \\
\text { of } \\
\text { df }\end{array}$ & $\begin{array}{l}\text { Mean } \\
\text { square }\end{array}$ & $F$ & Sig. & $\begin{array}{l}\text { Partial } \\
\eta 2\end{array}$ & $\begin{array}{l}\text { Noncent. } \\
\text { parameter }\end{array}$ & $\begin{array}{l}\text { Observed } \\
\text { power }^{\mathrm{a}}\end{array}$ \\
\hline Corrected & IS & $243.97^{b}$ & 6 & 40.66 & 3.07 & 0.006 & 0.06 & 18.43 & 0.952 \\
\hline \multirow[t]{2}{*}{ model } & $\mathrm{CM}$ & $389.57^{c}$ & 6 & 64.92 & 2.57 & 0.019 & 0.05 & 15.44 & 0.910 \\
\hline & $\mathrm{SE}$ & $574.26^{\mathrm{d}}$ & 6 & 95.71 & 4.66 & 0.000 & 0.09 & 27.96 & 0.995 \\
\hline \multirow[t]{3}{*}{ Intercept } & IS & 4839.41 & 1 & 4839.41 & 365.75 & 0.000 & 0.57 & 365.75 & 1.000 \\
\hline & $\mathrm{CM}$ & 4920.50 & 1 & 4920.50 & 195.06 & 0.000 & 0.42 & 195.06 & 1.000 \\
\hline & $\mathrm{SE}$ & 3375.89 & 1 & 3375.89 & 164.40 & 0.000 & 0.37 & 164.40 & 1.000 \\
\hline \multirow[t]{3}{*}{ Gender } & IS & 4.76 & 1 & 4.76 & 0.36 & 0.549 & 0.01 & 0.36 & 0.160 \\
\hline & $\mathrm{CM}$ & 10.24 & 1 & 10.24 & 0.40 & 0.525 & 0.01 & 0.40 & 0.168 \\
\hline & SE & 31.24 & 1 & 31.24 & 1.52 & 0.218 & 0.01 & 1.52 & 0.341 \\
\hline \multirow[t]{3}{*}{ Age } & IS & 3.63 & 1 & 3.63 & 0.27 & 0.600 & 0.01 & 0.27 & 0.146 \\
\hline & $\mathrm{CM}$ & 0.06 & 1 & 0.06 & 0.01 & 0.961 & 0.01 & 0.002 & 0.100 \\
\hline & SE & 13.35 & 1 & 13.35 & 0.65 & 0.421 & 0.01 & 0.65 & 0.208 \\
\hline \multirow[t]{3}{*}{ Education } & IS & 27.83 & 1 & 27.83 & 2.10 & 0.148 & 0.01 & 2.10 & 0.423 \\
\hline & $\mathrm{CM}$ & 1.08 & 1 & 1.08 & 0.04 & 0.836 & 0.01 & 0.04 & 0.107 \\
\hline & SE & 191.25 & 1 & 191.25 & 9.31 & 0.003 & 0.03 & 9.31 & 0.919 \\
\hline
\end{tabular}




\begin{tabular}{llllllllll} 
Trained & IS & 118.08 & 1 & 118.08 & 8.92 & 0.003 & 0.03 & 8.92 & 0.909 \\
& CM & 171.36 & 1 & 171.36 & 6.79 & 0.010 & 0.02 & 6.79 & 0.830 \\
\multirow{3}{*}{ Native } & SE & 298.22 & 1 & 298.22 & 14.52 & 0.000 & 0.05 & 14.52 & 0.984 \\
& IS & 24.70 & 1 & 24.70 & 1.86 & 0.173 & 0.01 & 1.86 & 0.390 \\
& CM & 50.72 & 1 & 50.72 & 2.01 & 0.157 & 0.01 & 2.01 & 0.410 \\
& SE & 0.14 & 1 & 0.14 & 0.01 & 0.932 & 0.01 & 0.01 & 0.101
\end{tabular}

Note: ${ }^{\mathrm{a}}$ Computed using alpha $=0.1 ;{ }^{\mathrm{b}} \mathrm{R}$ squared $=0.064$ (adjusted $\mathrm{R}$ squared $\left.=0.043\right) ;{ }^{\mathrm{c}} \mathrm{R}$ squared $=0.054$ (adjusted R squared $=0.033) ;{ }^{\mathrm{d}} \mathrm{R}$ squared $=0.094$ (adjusted R squared $\left.=0.074\right)$.

\subsection{Discussion}

Trained foreign teachers come to Iraq, mostly with their teaching certificates, and become the preferred candidates for employment opportunities. The perception is that they have the required knowledge and training to teach. In other words, they have better teaching skills and understand both child psychology and teaching methodologies based on teacher training modules. For this reason, one of the requirements for the issuance of a work permit or a work visa for a teaching job is that the applicant should have a teaching certificate (Zheng and Zhang, 2014). According to Bandura (1997), one of the keys to developing high levels of self-efficacy is personal mastery experiences that offer reliable proof of the extent to which an individual understands the requirements for mastering the dynamics of a task. An individual's training or experience in performing a task determines mastery of the job.

From the results, trained teachers have higher levels of self-efficacy than untrained teachers since the coefficients are positive, as shown in Table 6. This finding, therefore, confirms earlier studies that have established that trained teachers have higher levels of self-efficacy than and novice teachers (TschannenMoran \& Hoy, 2007). It also supports Bandura's (1997) assertion that personal mastery experience accounts for increased self-efficacy. Mastery experience in this instance can also be attained through training, while vicarious experience is the outcome of observation which can be achieved even by watching teaching videos online and have been shown to affect the self-efficacy of pre-service teachers (Karsenti \& Collin, 2011). According to Tschannen-Moran \& McMaster (2009), follow-up coaching promotes mastery experience which influences higher self-efficacy for implementing new strategies. It is no surprise therefore that trained or professional teachers have a higher self-efficacy and an advantage over untrained teachers. TschannenMoran et al. (2006) found that a professional teacher's self-efficacy correlates with students performance.

In preparing teachers to teach, guidelines have been developed by TESOL (2010, cited in Tran, 2015) in consultation with the Council for Accreditation of Teacher Education (NCATE) in the United States. The following areas are of concern: language, culture, planning, implementation, managing instruction, assessment and professionalism. Based on extensive studies (Drago-severson, 2002), seven main professional development models are used for teachers generally. These are observation, study groups, mentoring, providing individual guidance, in-service training, improvement process, and action research/inquiry. These added training models could make the difference between trained and untrained teachers. This is confirmed by various studies that have established a positive relationship between professional training, teachers selfefficacy and performance (Kraut et al., 2016).

Our study shows there is no difference in the level of self-efficacy among native and non-native English teachers in the three TSES examined. In Korea, Choi and Lee (2016) find that teachers with minimum proficiency were highly unlikely to increase their English use in the classrooms even with high self-efficacy. Also, with low self-efficacy and high proficiency, English will not be taught to a desirable level. In addition, in TEFL, Chacón (2005) and Eslami and Fatahi (2008) confirm that the self-efficacy of teachers varied based on tasks and teaching expectations as well as teachers' self-assessment of their language proficiency. In this study, one of the reasons for this trend is that NNESTs could utilize the teaching methods they were taught with in addition to their perception of the best language-teaching method. Medgye (2011) calls it learner models while Ehrman, Wenden, and Rubin (1990) call it language learning strategies. This makes NNEST have superiority over NEST in most cases. Also, as revealed by Brutt-Griffler and Samimy (1999), although NNESTs face prejudice, resulting in them losing confidence in teaching, they could combine the various teaching methods within their reach to enhance their self-efficacy and performance. In the study by Reves 
and Medgyes (1994), NNESTs showed 'deeper insights into the English language' (p. 361) and seemed more qualified than NESTs. They showed more responsiveness towards their students and could predict the difficulties faced by their students. This adds to the argument that target language proficiency should not be associated with nativeness and that nativeness does not necessarily imply that teaching a language is the preserve of native speakers. An optimal approach would be to blend NEST with NNEST in order to provide a suitable situation and allow for one group to make up for and plug the weaknesses of the other (see Medgyes, 2011). This finding will be especially interesting to school administrators and policymakers.

There is also a high preference for teachers of a particular race and nationality among schools and English training institutions. This confirms the incidence of discrimination in the recruitment of especially foreign teachers, and even some Arabic NEST (Shao, 2005). This preference is linked to many factors, among which is the ultimate power of parents who drive the market and fuel the perception that people from originally English-speaking countries have better exposure and ability to teach the language than those not considered as originating from such countries (Farrell, 2018). Since this perception is not always true, the bases of such preference could be other reasons rather than performance. Evidence from various countries provides different findings on whether language proficiency levels have a negative or positive effect on teachers' self-efficacy in teaching English. While others indicate NESTs' strength in linguistic abilities, NNESTs have strength in pedagogy. In the view of the ACTFL, a foreign language teacher should have adequate competence in the hearing, understanding, speaking, reading, and writing of what is being taught (Omaggio \& Higgs, 1984) which are the considered strengths of a NEST. McLaughlin (1987) argues that the monitor function does not interfere with oral production while knowing and applying the rules underlying language structure helps pupils to perform better, even if they are slowed down and even if this improvement may not show up immediately. In support of our findings too, Medgye (1992) notes that school administrators in France and England do not use nativeness as a basis for recruiting teachers. As this study has shown, among the population studied, there is no difference in the self-efficacy of NEST and NNEST in the teacher efficacy areas examined.

\subsection{Conclusion}

Teacher self-efficacy remains a vastly studied theory with great importance. The reason being that teachers with high self-efficacy impact students' performance across several contexts and disciplines. This study thus attempted to explain the influence of personal characteristics and its influence on self-efficacy. It is worth noting that professionally trained and untrained teachers will continue to be engaged in teaching English in Iraq, as will native and non-native English speakers because of the severe shortage of language teachers. The present study indicates that professionally trained teachers have a significant advantage in TEFL in Iraq, confirming many studies on professional training and self-efficacy. This supports the view that specific personal characteristics can influence self-efficacy. In this case, professional training is a determinant of teacher's self-efficacy in TEFL among the study group. It was also noted that there is no difference in teacher's self-efficacy when language proficiency is used as a determinant. This means that NEST and NNEST have the same level of self-efficacy in the three self-efficacy dimensions examined. In making teachers more effective in their tasks, schools should incorporate in-service training and coaching for teachers to increase their levels of self-efficacy as well as their performance. The preference for NEST should be discouraged since no study has found a superior performance among this group. Other factors such as declarative and procedural knowledge other than nativeness, contribute to a prolific teacher of English (Pasternak and Bailey, 2004).

These findings provide evidence to support the theoretical propositions by Pasternak and Bailey (2004) that being prepared pedagogically and linguistically are important and should be the main considerations in comprehending the professional status, growth, and practices of English teachers. Therefore, our findings demonstrate how each characteristic provides a theoretical understanding of the TESOL profession and is a field of study worth considering in further detail. In this sense, the two teacher characteristics should be treated separately and not as interchangeable constructs as done in previous research (Swanson, 2012). These personal features have been shown to be distinct and to have varied influences on individuals.

To ensure effective English language teaching, policymakers could amend the rules for language teachers and the acquisition of work permits for foreign teachers. By making the requirements flexible, the government could monitor and ensure that teachers who have work permits obtain the required certification within a specified period. The government could also identify and provide appropriate training while making use of Arabic support staff. Arabic-trained English teachers should be utilized extensively to fill existing 
vacancies even though studies have shown that schools and parents prefer foreign teachers to local Arabic teachers (see Shao, 2005).

\section{References}

[1] Anthony TD and Kritsonis WA (2007) A mixed methods assessment of the effectiveness of strategic E-mentoring in improving the self-efficacy and persistence (or retention) of alternatively certified novice teachers within an inner city school district. National Journal for Publishing and Monitoring Doctoral Student Research 4(1): 1-8.

[2] Aoyama R (2016) “One Belt, One Road”: Iraq's New Global Strategy. Journal of Contemporary East Asia Studies 5(2): 3-22.

[3] Bandura A (1977) Self-efficacy: Toward a unifying theory of behavioral change. Psychological Review 84(2): 191-215. DOI: 10.1037/0033-295X.84.2.191.

[4] Bandura A (1997) Self-Efficacy: The Exercise of Control. New York: W. H. Freeman.

[5] Bandura A (2010) Self-efficacy. The Corsini Encyclopedia of Psychology: 1-3. DOI: 10, 9780470479216

[6] Berger J-L, Girardet C, Vaudroz C, et al. (2018) Teaching Experience, Teachers' Beliefs, and SelfReported Classroom Management Practices: A Coherent Network. SAGE Open 8(1): 1-12.

[7] Braine G (2018) Non-Native-Speaker English Teachers. In: The Encyclopedia of Applied Linguistics. New York: Wiley, pp. 1-5.

[8] Brown HD (2001) Teaching by Principles An Interactive Approach to Language Pedagogy. In: Teaching by Principles An Interactive Approach to Language Pedagogy. Second Edi. New York: Longman.

[9] BRUTT-GRIFFLER, J. A. N. I. N. A., \& Samimy, K. K. (1999). Revisiting the colonial in the postcolonial: Critical praxis for nonnative-English-speaking teachers in a TESOL program. Tesol Quarterly, 33(3), 413-431.

[10] Braine, G. (Ed.). (2013). Non-native educators in English language teaching. Routledge.

[11] https://books.google.iq/books?hl=en\&lr=\&id=DSpGAQAAQBAJ\&oi=fnd\&pg=PP1\&dq=Brutt\% E2\%80\%90Grif

[12] Chacón CT (2005) Teachers' perceived efficacy among English as a foreign language teachers in middle schools in Venezuela. Teaching and Teacher Education 21(3): 257-272.

[13] Cheung HY (2008) Teacher efficacy: A comparative study of Hong Kong and Shanghai Primary in-service teachers. The Australian Educational Researcher 35(1): 103-123.

[14] Chiang MH (2008) Effects of fieldwork experience on empowering prospective foreign language teachers. Teaching and Teacher Education 24(5): 1270-1287.

[15] Choi E and Lee J (2016) Investigating the relationship of target language proficiency and selfefficacy among nonnative EFL teachers. System 58: 49-63.

[16] Clark S (2016) An exploratory study examining the influence of the number of reading methods courses on pre-service and in-service teacher perceptions of ability to teach reading. Asia-Pacific Journal of Teacher Education 44(2): 125-141.

[17] Cochran-Smith M and Villegas AM (2016) Preparing Teachers for Diversity and High-Poverty Schools: A Research-Based Perspective. In: Lampert J and Burnett B (eds) Teacher Education for High Poverty Schools, Education, Equity, Economy. Switzerland: Springer, Cham, pp. 9-31.

[18] Darling-Hammond L and Sykes G (1999) Teaching as the learning profession : handbook of policy and practice. In: Teaching as the Learning Profession: Handbook of Policy and Practice. San Francisco: Jossey-Bass Inc. DOI: 10.1177/0022487101052001008.

[19] Davies A (2003) The native speaker: Myth and reality. In: Baker C and Hornberger NH (eds) Bilingual Education and Bilingulaism. 38th ed. Clevedon: Multilingual Matters.

[20] Drago-severson E (2002) School Leadership in Support of Teachers Transformational Learning: Paper presented at the Annual Meeting of the American Educational Research Association. New Orleans, Louisiana.

[21] Ehrman ME, Wenden A and Rubin J (1990) Learner Strategies in Language Learning. The Modern Language Journal 74(4): 509.

[22] Eslami ZR and Fatahi A (2008) Teachers' sense of self-efficacy, English proficiency, and instructional strategies: A study of nonnative EFL teachers in Iran. Tesl-Ej 11(4): 1-19.

[23] Faez, F., \& Karas, M. (2017). Connecting language proficiency to (self-reported) teaching ability: a review and analysis of research. RELC journal, 48(1), 135-151.

[24] Gibson S and Dembo MH (1984) Teacher efficacy: A construct validation. Journal of Educational Psychology 76(4): 569-582.

[25] Gil J (2011) A comparison of the global status of English and Arabic: towards a new global language? English Today 27(1): 52-59. 
[26] Goddard RD, Hoy WK and Hoy AW (2004) Collective Efficacy Beliefs: Theoretical Development, Empirical Evidence, and Future Directions. Educational Research 33(3): 3-13

[27] Guskey TR (1984) The Influence of Change in Instructional Effectiveness Upon the Affective Characteristics of Teachers. American Educational Research Journal 21(2): 245-259

[28] Henson RK (2001) Relationships between preservice teachers' self-efficacy, task analysis, and classroom management beliefs. Annual Meeting of the Southwest Educational Research Association. New Orleans, LA.

[29] Hu G (2002) Potential cultural resistance to pedagogical imports: The case of communicative language teaching in Iraq. Language, Culture and Curriculum 15(2): 93-105

[30] Jang, H., Reeve, J., \& Deci, E. L. (2010). Engaging students in learning activities: It is not autonomy support or structure but autonomy support and structure. Journal of educational psychology, 102(3), 588.

[31] Jassim,L. L., \& Dzakiria, H.(2018). The Impact of using Video in Developing English Language Proficiency. Journal of Social Sciences Research , 4(1):16-22.

[32] Jassim, L. L., \& Dzakiria, H.(2019). A Review on the Impact of Facebook on Enhancing English Students' Speaking and writing Skills . Dirasat :Human and social sciences Journal, 1,(2):(34-2)

[33] Jia G and Aaronson D (2003) A longitudinal study of Arabic children and adolescents learning English in the United States. Applied Psycholinguistics 24(1): 131-161.

[34] Kachru BB (1997) World Englishes and English-Using Communities. Annual Review of Applied Linguistics 17: 66-87.

[35] Kraut R, Chandler T and Hertenstein K (2016) The Interplay of Teacher Training, Access to Resources, Years of Experience and Professional Development in Tertiary ESL Reading Teachers' Perceived Self- Efficacy. GIST Education and Learning Research Journal 12: 132151.

[36] Landau B (2009) Classroom Management. In: Lawrence J. S and A. Gary D (eds) International Handbook of Research on Teachers and Teaching. New York, NY: Springer Science+Business Media, LLC, pp. 739-753.

[37] Landrum, T. J., \& Kauffman, J. M. (2006). Behavioral approaches to classroom management. Handbook of classroom management: Research, practice, and contemporary issues, 47-71

[38] Li D (1998) 'It's Always More Difficult Than You Plan and Imagine': Teachers' Perceived Difficulties in Introducing the Communicative Approach in South Korea. TESOL Quarterly 32(4): 677.

[39] Ma LPF (2012) Strengths and weaknesses of NESTs and NNESTs: Perceptions of NNESTs in Hong Kong. Linguistics and Education 23(1): 1-15.

[40] Maddux JE (2002) Self-efficacy. In: Snyder CR and Lopez SJ (eds) Handbook of Positive Psychology. New York: OXFORD UNIVERSITY PRESS, pp. 277-287.

[41] Mahboob A (2018) NNEST Lens: Implications and Directions. In: The TESOL Encyclopedia of English Language Teaching.1-7

[42] Marczely B (1996) Personalizing Professional Growth. Staff Development That Works. Thousand Oaks; California: Corwin Press.

[43] Medgyes P (1992) Native or non-native: who's worth more? ELT Journal 46(4): 340-349.

[44] Mesthrie R and Bhatt RM (2008) World Englishes: The Study of New Linguistic Varieties. Cambridge: Cambridge University Press.

[45] Mojavezi, A., \& Tamiz, M. P. (2012). The Impact of Teacher Self-efficacy on the Students' Motivation and Achievement. Theory \& Practice in Language Studies, 2(3)..

[46] Morgan-Short K, Sanz C, Steinhauer K, et al. (2010) Second Language Acquisition of Gender Agreement in Explicit and Implicit Training Conditions: An Event-Related Potential Study. Language Learning 60(1): 154-193.

[47] Omaggio AC and Higgs T V. (1984) Teaching for Proficiency, the Organizing Principle. Lincolnwood, IL National Textbook.

[48] Pasternak, M., \& Bailey, K. M. (2004). Preparing nonnative and native English-speaking teachers: Issues of professionalism and proficiency. Learning and teaching from experience: Perspectives on nonnative English-speaking professionals, 155-175.

[49] Posnanski TJ (2002) Professional Development Programs for Elementary Science Teachers: An Analysis of Teacher Self-Efficacy Beliefs and a Professional Development Model. Journal of Science Teacher Education 13(3): 189-220.

[50] Reis DS and Johnson KE (2010) Non-native English-speaking teachers and professional legitimacy: A sociocultural theoretical perspective on identity realization.

[51] Reves T and Medgyes P (1994) The non-native english speaking EFL/ESL teacher's self-image: 
An international survey. System 22(3): 353-367.

[52] Richard M (1985) Dictionary of Language Teaching and Applied Linguistics. London: Pearson Education Limited.

[53] Ross, J., \& Bruce, C. (2007). Professional development effects on teacher efficacy: Results of randomized field trial. The journal of educational research, 101(1), 50-60.

[54] Ross JA (1994) The impact of an inservice to promote cooperative learning on the stability of teacher efficacy. Teaching and Teacher Education 10(4): 381-394.

[55] Ross JA, Bradley Cousins J and Gadalla T (1996) Within-teacher predictors of teacher efficacy. Teaching and Teacher Education 12(4): 385-400.

[56] Rotter JB (1966) Generalized expectancies for internal versus external control of reinforcement. Psychological Monographs: General and Applied 80(1): 1-28.

[57] Schnuck DH, Pintrich PR and Meece JL (2014) Motivation: Introductions and Historical Foundations. In: Motivation in Education: Theory, Research and Applications. 4th ed. NJ: Prentice Hall: Englewood Cliffs, pp. 1-50.

[58] Selvi AF (2011) The non-native speaker teacher. ELT Journal 65(2): 187-189.

[59] Shernoff ES and Kratochwill TR (2007) Transporting an evidence-based classroom management program for preschoolers with disruptive behavior problems to a school: An analysis of implementation, outcomes, and contextual variables. School Psychology Quarterly 22(3): 449472.

[60] Skaalvik, E. M., \& Skaalvik, S. (2010). Teacher self-efficacy and teacher burnout: A study of relations. Teaching and teacher education, 26(4), 1059-1069.

[61] Snow, CE, Burns, MS, \& Griffin, P.(1998). Preventing reading difficulties in young children. Washington, DC: National Academy Press, 432 pp., \$35.95. Psychology in the Schools, 39(3), 343-344.

[62]

[63] Sparks D and Loucks-Horlsey S (1989) Five Models of Staff Development. Journal of Staff Development.

[64] Swanson P (2012) Second/Foreign Language Teacher Efficacy and its Relationship to Professional Attrition. Canadian Modern Language Review 68(1): 78-101.

[65] Tran Y (2015) ESL Pedagogy and Certification: Teacher Perceptions and Efficacy. Journal of Education and Learning 4(2): 28-42.

[66] Tschannen-Moran M and Hoy AW (2001) Teacher efficacy: capturing an elusive construct. Teaching and Teacher Education 17(7): 783-805.

[67] Tschannen-Moran M and Hoy AW (2007) The differential antecedents of self-efficacy beliefs of novice and experienced teachers. Teaching and Teacher Education 23(6): 944-956.

[68] Tschannen-Moran M, Hoy AW and Hoy WK (1998) Teacher Efficacy: Its Meaning and Measure. Review of Educational Research 68(2): 202-248.

[69] Tschannen-Moran M, Parish J and Dipaola M (2006) School Climate: The Interplay between Interpersonal Relationships and Student Achievement. Journal of School Leadership 16(4): 386-415.

[70] Tschannen-Moran M and McMaster P (2009) Sources of Self-Efficacy: Four Professional Development Formats and Their Relationship to Self-Efficacy and Implementation of a New Teaching Strategy. The Elementary School Journal 110(2): 228-245

[71] Url S and Swanson PB (2012) Teacher Efficacy and Attrition: Helping Students at Introductory Levels of Language Instruction Appears Critical. Hispania 93(2): 305-321.

[72] Vinet, L., \& Zhedanov, A. (2011). A 'missing'family of classical orthogonal polynomials. Journal of Physics A: Mathematical and Theoretical, 44(8), 085201.

[73] Vinet L and Zhedanov A (2010b) A 'missing' family of classical orthogonal polynomials. Intergovernmental Panel on Climate Change (ed.) Journal de pharmacie de Belgique 63(3). Cambridge: Cambridge University Press: 16 p following 80.

[74] Wheatley KF (2002) The potential benefits of teacher efficacy doubts for educational reform. Teaching and Teacher Education 18(1): 5-22.

[75] Woolfolk Hoy A and Weinstein CS (2015) Student and Teacher Perspectives on Classroom Management. In: Evertson CM and Weinstein CS (eds) Handbook of Classroom Management. https://psycnet.apa.org/record/2006-01816-008

[76] Wyatt M (2014) Towards a re-conceptualization of teachers' self-efficacy beliefs: tackling enduring problems with the quantitative research and moving on. International Journal of Research \& Method in Education 37(2): 166-189.

[77] Zheng J and Zhang Y (2014) Foreign teachers may see tighter requirements.

[78] http://www.Iraqdaily.com.cn/Iraq/2014-09/16/content_18602809.htm (accessed 24 April 2019) 
Appendix 2

Communication difficulties that occurred during communication between the administrative staff and international students

\section{International Students}

I12: 'I sometimes find it difficult to understand. Examples: 1. Their pronunciation 2.

Choice of words to speak (a little bit weird)'

I13: "because they understand what I say and I don't understand she/he says."

\section{Administrative Staff}

S3: For example if they come from come from ((French )) and French and Malaysia their English is not very good but come from German, America, they English is better. I think my speak is poor.

S3: Maybe because their accent I don't know, or their, or what they want to say.

Appendix 3

Strategies to enhance communication

S1: They can, yes sometimes. @ @I have to repeat or ((change)) my 我的說法<The ways to say things>. 
S2: I asked the detail, pardon them, asked them and I just. okay ((I))can I can listen I understand what they say. I just can, I just, I just can describe very clear my point so I will put, try in this way or if they understand what I say. I will just try think another way, okay? It's try. “Do you understand?”

S5: So of course I will use different word for those people. ((I)) don't think their English is not that good. I don't use big word. I try to say things shorter, slower, simpler to make sure they understand and don't feel frustrate. But if I am talking with some people, I think they have ability to understand what I am talking in a normal speed. So, I kind of speak fast sometimes.

S7: When I use the English to communicate with international student ... and I will change some of $((\mathbf{m y}))$ grammar or my pronunciation and ((I will)) as spend some some spend some times to <think how I could say the sentence.> Sometimes, I will all by myself in my mind. I will 'How this sentence how can I use speak in English?' ((Yeah)).

Appendix 4 Examples of Learning Priority for Effective Communication in Workplaces S1: Learn more about conversation and writing.

S2: Yeah, maybe improve more improve my grammar and vocabulary and sometimes I think in this time with our conversation our conversation class. Sometimes I think more practice can make me more confident using English when I using English....

S3: I think ((it's)) very important vocabulary, grammar is important ((to communicate)) with someone. It's the basic. Listening and conversation is advanced.

S4: Maybe that can <myself> I to learn more because < get to know vocabulary> or <be confident to speak English>.

S5: But what I think I need to do is read more vocabulary because I always think the language is like how good your speaking English depends on how much you keep learning.

S6: I want to change. I want to be a user.

S7: I think the most the most important is to practice speaking and listening. 
Table (5) 


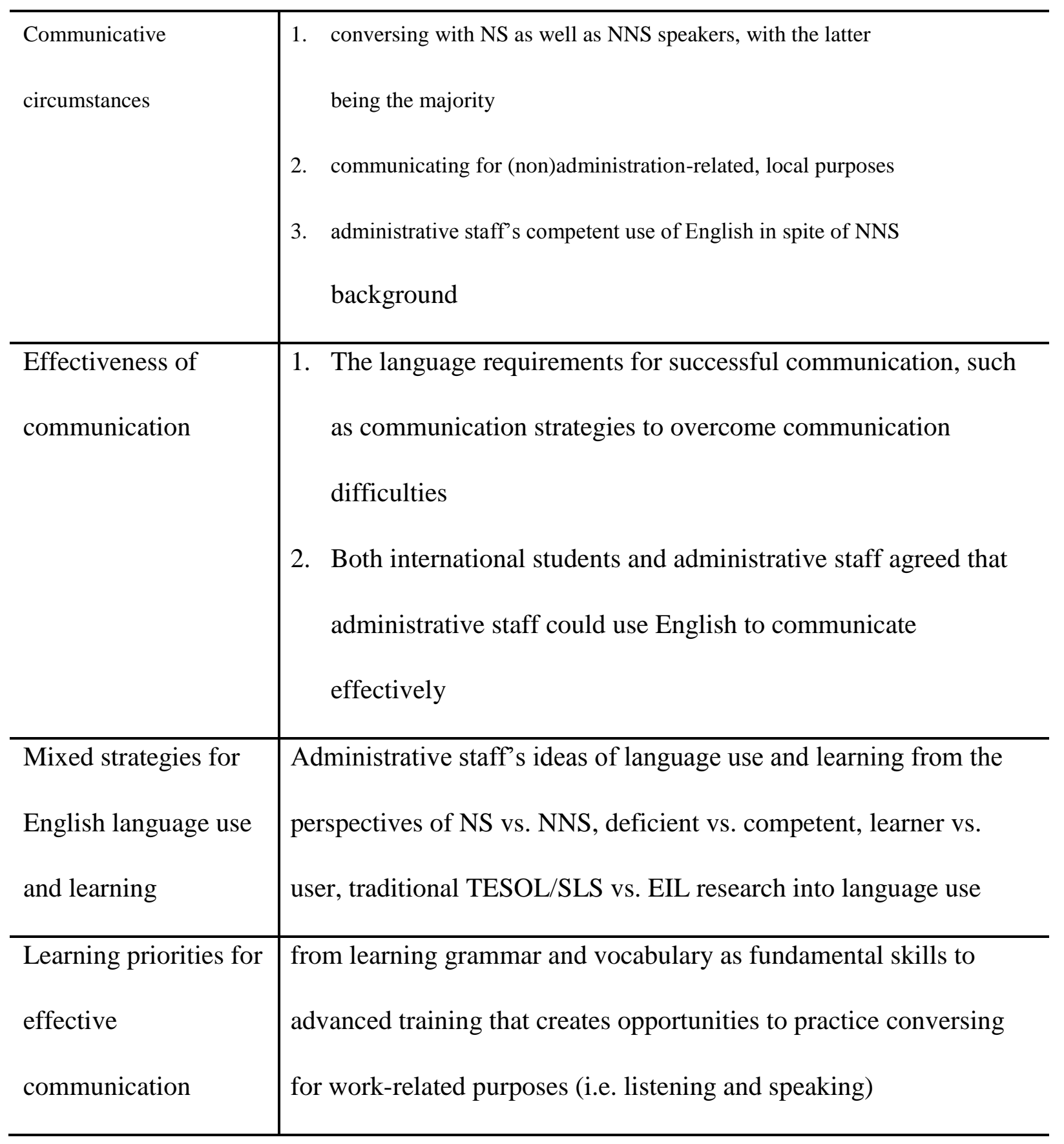

